\title{
Features of Identification Business Processes
}

\author{
Runova E. V. ${ }^{1,2}$, Vdovina S. D. ${ }^{2} \&$ Khafizova L. V. ${ }^{1}$ \\ ${ }^{1}$ Kazan Federal University, Institute of Management, Economics and Finance, Kazan, Russia \\ ${ }^{2}$ Russian University of Cooperation (Kazan Institute), Kazan, Russia \\ Correspondence: Khafizova L. V., Kazan Federal University, Institute of Management, Economics and Finance, \\ Kazan, 420008, Russia. Tel: 7-927-443-0169. E-mail: liliakhafizova13@gmail.com
}

Received: December 27, 2014 Accepted: February 19, 2015 Online Published: April 30, 2015

doi:10.5539/ass.v11n11p76 URL: http://dx.doi.org/10.5539/ass.v11n11p76

\begin{abstract}
This article deals with the peculiarities of identifying business processes. Identification of business processes is the most important stage in the development of business processes used by business analysts and enterprise architects to construct models of business processes. The aim of the study is to identify the problems for proper operation of business processes. The identification of business processes is based on their selection by different classification groups. This is due to the fact that it is not always clear in which business process a unit which has its own functional structure is involved. The paper presents the author's method of identifying the business processes, which is tested on a particular company. The article demonstrates the key aspects that must be taken into account during identification. During the identification of business processes organization considers their scope, length and level of detail. The authors propose to divide the business processes into problematic and unproblematic. Unproblematic business processes do not require intervention of the company management. Problematic business processes require active intervention and strict control of the company's management. The paper used a combination of two powerful methods - mathematical- economic and expertise ones that offer significant advantages in the identification of management business processes.
\end{abstract}

Keywords: identification, management, business processes, problem business processes, concordance coefficient, Harrington scale, ranking

\section{Introduction}

According to IDC forecasts, by the end of 2014 the global market of business process management means will grow by $16 \%$ and amount to almost $\$ 11$ billion. Studies have shown that this occurs even during crisis, and over a third of the companies did not cut spending on business process management while $29 \%$ reduced costs in general, but continued to develop the system.

In the Russian market business processes management is only developing. At this stage, Development Directors have a lot of questions about using the tools that will construct business process management in the organization. Here, it is the identification of business processes and their description that have primacy, because it helps to identify problems with a particular business process (Terziovski, Fitzpatrick, \& O'Neill, 2003).

According to studies, almost every fourth Russian company has all business processes described, and $60 \%$ - only the key processes. Branches of Russian business, where the business processes are most often identified and described are represented fully in Figure 1.

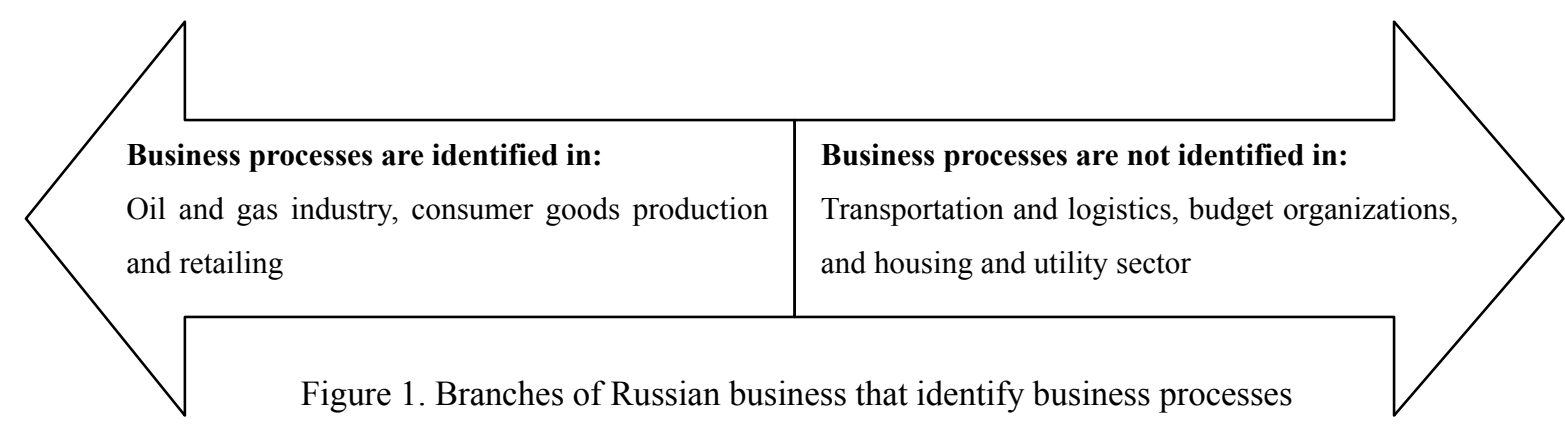


Such foreign scholars as M. Hammer, J. Champi, T. Davenport, M. Porter, D. Peppard, Manganelli and Klein and others devoted their work to identifying business processes of enterprises in one way or another.

Identification in general is understood as a choice of simple and clearly perceptible means of defining the business process as a digital, graphic or verbal notation, symbols of color overlays, etc. on the business process documents, diskettes and other media of business processes, which can quickly and unambiguously identify the specific business process in the existing set of processes and determine the order of their execution.

One of the approaches to the identification of business processes is based on value chain that is described by M. Porter, which highlights the main (primary) business processes to ensure the creation of product customer value and the support (secondary) business processes to ensure the functioning of the business and to accompany creation of product throughout its life cycle.

The founders of business process reengineering J. Champi and M. Hammer believe that the identification of business processes involves the assessment of their relationship with the external and internal environment, resulting in a graphic description of all business processes. The main goal is a complete process transformation, radical in nature that limits bureaucratic structure in organization to core process specialization (Ringim, Osman, \& Razalli, 2013).

T. Davenport, unlike J. Champi and M. Hammer, believed that there is no need to describe all business processes. It is sufficient to select several (up to 15) business processes and describe them.

Manganelli and Klein propose to concentrate only on those business processes that directly support the strategic goals of the company and provide customer needs.

It is also advisable to consider two mutually complementary approaches developed by D. Peppard (Peppard, 1998). In the first case it is proposed to make a list of all business processes in the enterprise, which are of importance for it. Another option involves a sequence of elements: the formation of the organization's strategy and its targets; selection of stakeholders; certain expectations of the products or services marketed by the company; distinguishing business processes, that produce a product or a service, as well as their support and the possibility to produce them.

When following the sequence it is much easier to identify business processes because it is known what stakeholders expect. Identifying the business processes begins after determining the requirements of stakeholders (Wood \& Dixon, 2011).

The main problem of all these approaches is the lack of a single tool to identify business processes.

Thus, despite the great attention to the study of the business processes of enterprises and their identification, in practice, many managers do not rely on scientific development, and operate intuitively. To solve the problem of the lack of a unified approach to the theory and practice of identifying the enterprises business processes it is necessary to improve the system of company management (Al-Mashari \& Zairi, 1999).

\section{Method}

Methods of identifying business processes, we offer, involve the following steps below.

Firstly, strategic goals are set, then stakeholders are distinguished, from whom a working group for identifying the business processes of companies is formed. After that, problematic and unproblematic business processes are defined. This classification feature implies assessing the impact of business processes on the activities of organization. The necessity of such a classification is caused by the fact that it is not always worthwhile for a company to improve the well-run business processes, because they are already effective. It is necessary to identify problematic business processes and to eliminate the cause of malfunction (Gong \& Janssen, 2012).

We have determined the following criteria for identifying problematic and unproblematic organization business processes: the importance of business process; problematic nature of the business process; the impact of a business process on the activities of a firm; possibility, time and cost of changing the business process.

Identification of business processes is conducted on the basis of expert assessments, reflected in a special questionnaire. It allows to organize the information available about the functioning business processes. The results of the questionnaire are presented in tabular form. It will contain the evaluation on the organization and the conclusions drawn.

Among the main, support and management business processes, problematic and unproblematic business processes are identified by rank (the more problematic is the business process, the higher the rank is) which are analyzed and experts decide to change them. 
The sequence of actions to identify business processes involves several stages, as shown in Figure 2.

Stage 1 . To determine the list of main, support and management of business processes.

Stage 2. The expert assesses the potential impact of each business process on financial and economic activity of the enterprise (on a scale from 0 to 10). The higher the impact of the business process is, the higher is the score.

Stage 3.To assess severity of problems according to the scale of Harrington of each business process (Harrington. Esseling. \& Nimwegen, 1997).

Stage 4. To estimate the work significance by product of the severity of the problems on the degree of influence.

Stage 5. To determine the rank of the business process on the basis of major importance. The higher the rank, the worse a business process, and the sooner the activities to improve it are required.

Stage 6. The coefficient of concordance is calculated, which will allow to determine the consistency of the expert rankings. If relation is noticeable or strong, then ranking of business processes is produced. If relation is moderate, weak or absent, the inconsistency of expert opinions is observed which will necessitate reviewing the rankings and justifications of ranks.

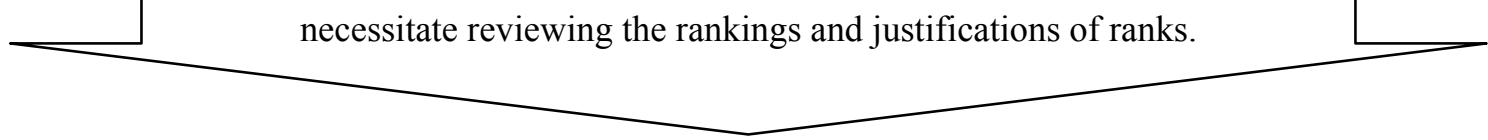

Stage 7. To define the problematic and unproblematic business processes in terms of basic, support and management business processes. Problematic and unproblematic business process is defined by calculating the significance and using two parameters - the degree of impact and severity of problems. The boundaries of significance are determined by the product of impact on the severity of the problems. The resulting scale is as follows: High importance: $0 \div 0,95$, average

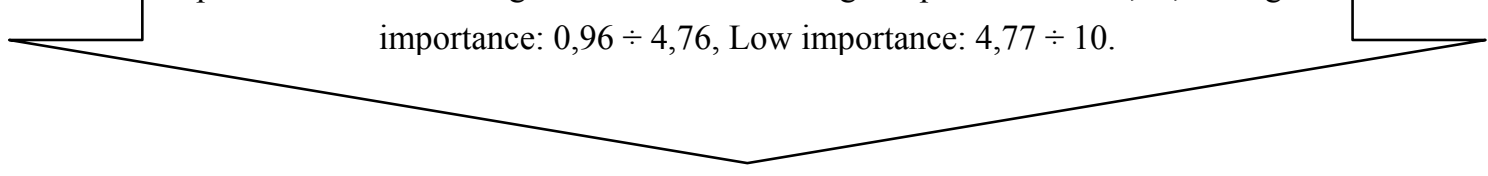

Figure 2. Stages for identifying business processes

According to the proposed sequence the last two stages are of the greatest complexity. This is due to the ongoing calculations. Thus, at stage 6 coefficient of concordance is calculated:

$$
\mathrm{W}=12 \mathrm{xS} / \mathrm{m}^{2} \mathrm{x}\left(\mathrm{n}^{3}-\mathrm{n}\right)
$$

where: $\mathrm{m}$ - the number of experts, 
$\mathrm{n}$ - the number of business processes,

$\mathrm{x}_{\mathrm{ij}}-i$ factor assessment, given by $\mathrm{j}$-th expert,

$\mathrm{w}_{\mathrm{ij}}$ - weight of $\mathrm{i}$ business process, calculated by $\mathrm{j}$-th expert marks, $\mathrm{w}_{\mathrm{ij}}=0,1$, if $\mathrm{w}_{\mathrm{ij}}=1$, then all experts ranked business processes uniformly,

$\mathrm{s}$ - average sum of ranks (when summing for each business process), received by $i$ business processes from experts:

$$
S=\sum_{i=1}^{n}\left(\sum_{j=1}^{m} x_{i j}-\frac{1}{2} m(n+1)\right)^{2}
$$

The closer is concordance coefficient to zero, the less are consistent estimates of experts. Following common practice if:

$\mathrm{W}=0,1 \div 0,3$, then correlation is weak, $\mathrm{W}=0,3 \div 0,5$, then correlation is moderate, $\mathrm{W}=0,5 \div 0,7$, then correlation is noticeable, $\mathrm{W}=0,7 \div 0,99$, then correlation is high.

The calculations made allow us to rank business processes and identify the most problematic among the main, auxiliary and management business processes.

\section{Results}

Application of the proposed methods for identifying business processes will give significant benefits for enterprises. These advantages are shown in Table 1 in accordance with the requirements of the key stakeholders.

Table 1. Advantages of the author's methods of identifying business processes

\begin{tabular}{ll}
\hline Stakeholders & The advantages received \\
\hline Owners & $\begin{array}{l}\text { Costs reduction for identifying and managing business processes of an enterprise, time } \\
\text { saving for identifying problematic and unproblematic business processes, improving the } \\
\text { quality of business processes at the enterprise }\end{array}$ \\
Availability of regulations for problematic business processes, which enables to control \\
the course of improving business process \\
Reducing disruptions in supply of raw materials, reducing the time for conclusion and \\
monitoring of supply contracts \\
Buyers
\end{tabular}

\section{Conclusions}

As seen from the above said, author's method of identifying business processes can be useful at all stages of the business improvement. Using identification of business processes will reduce the cost and time for implementation of the business process. We can say with confidence that the combination of expert and mathematical approach to the identification gives the most accurate results and in the long term will enable to achieve profit maximization of organization.

\section{References}

Al-Mashari, M., \& Zairi, M. (1999). Business process reengineering implementation processes: an analysis of key success and failure factors. Business Process Management Journal, 5(1), 87-112.

Bagautdinova, N. G., Galieva, G. T., Pakhmutov, Ya. O., \& Pratchenko, O. V. (2014). Methods of Regulation of Processes of Innovation Business Development. Mediterranean Journal of Social Sciences, 5(12), 241-246.

Gong, Y., \& Janssen, M. (2012). From policy implementation to business process management: Principles for creating flexibility and agility. Government Information Quarterly, 29, 61-71.

Harrington, H. J., Esseling, K., \& Nimwegen, V. (1997, April 1). Business Process Improvement Workbook: Documentation, Analysis, Design, and Management of Business Process Improvement Hardcover. 
Kalenskaya, N., \& Shafigullina, A. (2014). The Invariance as a Feature of Business Systems' Infrastructural Innovative Development. Mediterranean Journal of Social Sciences, 5(18), 241-246.

Norton, D., \& Kaplan, R. (1996). Using the Balanced Scorecard as a Strategic Management System. Harvard Business Review, January-February.

Peppard, J. (1998). Benchmarking Business Process: A Framework and Classification Scheme. In Proceedings of the ESPRIT-COPERNICUS Symposium, Distributed Enter prise, Intelligent Automation, and Industrial Benchmarking, Wroclaw, Poland.

Ringim, K. J., Osman, N. H., \& Razalli, M. R. (2013). Exploring the Implementation of Business Process Reengineering in Banks. Asian Social Science, 9(11), 243-253.

Safiullin, M. R., Elstin, L. A., \& Shakirova, A. I. (2012). Evaluation of business and economic activity as a short-term forecasting tool. Herald of the Russian Academy of Sciences, (4), 290-294.

Suetina, T. A., Odinokov, M. Y., \& Safina, D. M. (2014). Benefits of Project Management at Lean Manufacturing Tools Implementation. Asian Social Science, 10(20), 62-66.

Terziovski, M., Fitzpatrick, P., \& O'Neill, P. (2003). Successful predictors of business process reengineering (BPR) in financial services. International Journal of Production Economics, 84(1), 35-50.

Wood, L. N., \& Dixon, P. (2011). Stakeholder Analysis: Using the Jigsaw Method for Ethical Dilemmas in Business. Asian Social Science, 7(4), 77-83.

\section{Copyrights}

Copyright for this article is retained by the author(s), with first publication rights granted to the journal.

This is an open-access article distributed under the terms and conditions of the Creative Commons Attribution license (http://creativecommons.org/licenses/by/3.0/). 